\title{
Annex 4: Inventory of relevant EU legal and regulatory instruments for border management ${ }^{1}$
}

\author{
Alessandra CALVI \\ Vrije Universiteit Brussel.E-mail: alessandra.calvi@vub.be.
}

\subsection{Primary law}

- Treaty on the European Union ${ }^{2}$

- in particular: Article 3(2)

- Treaty on the Functioning of the European Union ${ }^{3}$

- in particular: Title V Area of Freedom, Security and Justice

- Protocol (No. 19) on the Schengen acquis integrated into the framework of the European Union

- Protocol (No. 21) on the position of the United Kingdom and Ireland in respect of the area of freedom, security and justice

- Protocol (No. 22) on the position of Denmark

- Protocol (No. 23) on external relations of the Member States with regard to the crossing of external borders

- Protocol (No. 24) on asylum for nationals of Member States of the European Union

- Declaration (36) on Article 218 of the Treaty on the Functioning of the European Union concerning the negotiation and conclusion of international agreements by Member States relating to the area of freedom, security and justice

- Charter of Fundamental Rights of the European Union ${ }^{4}$ 


\subsection{Secondary law}

\section{Schengen and Schengen Information System (SIS)}

- Agreement between the Governments of the States of the Benelux Economic Union, the Federal Republic of Germany and the French Republic on the gradual abolition of checks at their common borders (14 June 1985) ${ }^{5}$

- Convention Implementing the Schengen Agreement of 14 June 1985 between the Governments of the States of the Benelux Economic Union, the Federal Republic of Germany and the French Republic, on the gradual abolition of checks at their common borders (19 June 1990) ${ }^{6}$

- Regulation (EC) No. 1986/2006 of the European Parliament and of the Council of 20 December 2006 regarding access to the second-generation Schengen Information System (SIS II) by the services in the Member States responsible for issuing vehicle registration certificates (cooperation on vehicle registration) ${ }^{7}$

- Regulation (EC) No. 1987/2006 of the European Parliament and of the Council of 20 December 2006 on the establishment, operation and use of the second-generation Schengen Information System (SIS II) (border control cooperation) ${ }^{8}$

- Annex to the Commission Recommendation establishing a common "Practical Handbook for Border Guards" to be used by Member States' competent authorities when carrying out the border control of persons and replacing Commission Recommendation C(2006) 5186 of 6 November 2006 [C(2019) 7131 final]

- Council Decision 2007/533/JHA of 12 June 2007 on the establishment, operation and use of the second-generation Schengen Information System (SIS II) (law enforcement cooperation $)^{9}$

- Commission Decision 2010/261/EU of 4 May 2010 on the Security Plan for Central SIS II and the Communication Infrastructure ${ }^{10}$

- Regulation (EU) 2016/399 of the European Parliament and of the Council of 9 March 2016 on a Union Code on the rules governing the movement of persons across borders (Schengen Borders Code) ${ }^{11}$

- Commission Implementing Decision 2013/115/EU of 26 February 2013 on the Sirene Manual and other implementing measures for the second generation Schengen Information System (SIS II) ${ }^{12}$

- Commission Implementing Decision (EU) 2017/1528 of 31 August 2017 replacing the Annex to Implementing Decision 2013/115/EU on the SIRENE Manual and other implementing measures for the second generation Schengen Information System $(\text { SIS II })^{13}$ [C(2017) 5893]

- Regulation (EU) 2018/1860 of the European Parliament and of the Council of 28 November 2018 on the use of the Schengen Information System for the return of illegally staying third-country nationals ${ }^{14}$ 
- Regulation (EU) 2018/1861 of the European Parliament and of the Council of 28 November 2018 on the establishment, operation and use of the Schengen Information System (SIS) in the field of border checks, and amending the Convention implementing the Schengen Agreement, and amending and repealing Regulation (EC) No. 1987/2006 15

- Regulation (EU) 2018/1862 of the European Parliament and of the Council of 28 November 2018 on the establishment, operation and use of the Schengen Information System (SIS) in the field of police cooperation and judicial cooperation in criminal matters, amending and repealing Council Decision 2007/533/JHA, and repealing Regulation (EC) No. 1986/2006 of the European Parliament and of the Council and Commission Decision 2010/261/EU ${ }^{16}$

- Proposal COM(2020) 791 final [2020/0350(COD)] for a Regulation of the European Parliament and of the Council amending Regulation (EU) 2018/1862 on the establishment, operation and use of the Schengen Information System (SIS) in the field of police cooperation and judicial cooperation in criminal matters as regards the entry of alerts by Europol

\section{Visa Information System (VIS)}

- Council Decision 2004/512/EC of 8 June 2004 establishing the Visa Information System (VIS) ${ }^{17}$

- Regulation (EC) No. 767/2008 of the European Parliament and of the Council of 9 July 2008 concerning the Visa Information System (VIS) and the exchange of data between Member States on short-stay visas (VIS Regulation) $)^{18}$

- Council Decision 2008/633/JHA of 23 June 2008 concerning access for consultation of the Visa Information System (VIS) by designated authorities of Member States and by Europol for the purposes of the prevention, detection and investigation of terrorist offences and of other serious criminal offences ${ }^{19}$

- Regulation (EC) No. 810/2009 of the European Parliament and of the Council of 13 July 2009 establishing a Community Code on Visas ${ }^{20}$

- Commission Decision 2006/648/EC of 22 September 2006 laying down the technical specifications on the standards for biometric features related to the development of the Visa Information System ${ }^{21}$ [C(2006) 3699]

- Commission Implementing Decision amending Commission Decision No. C(2010) 1620 final of 19 March 2010 establishing the Handbook for the processing of visa applications and the modification of issued visa ("Visa Handbook") [C(2019) 3464 final]

- Proposal COM(2018) 302 final [2018/0152(COD)] Proposal for a Regulation of the European Parliament and of the Council amending Regulation (EC) No. 767/2008, Regulation (EC) No. 810/2009, Regulation (EU) 2017/2226, Regulation (EU) 2016/399, Regulation XX/2018 [Interoperability Regulation], and Decision 2004/512/EC and repealing Council Decision 2008/633/JHA 


\section{European Dactyloscopy (Eurodac)}

- Regulation (EU) No. 604/2013 of the European Parliament and of the Council of 26 June 2013 establishing the criteria and mechanisms for determining the Member State responsible for examining an application for international protection lodged in one of the Member States by a third-country national or a stateless person (recast) ${ }^{22}$

- Regulation (EU) No. 603/2013 of the European Parliament and of the Council of 26 June 2013 on the establishment of 'Eurodac' for the comparison of fingerprints for the effective application of Regulation (EU) No. 604/2013 establishing the criteria and mechanisms for determining the Member State responsible for examining an application for international protection lodged in one of the Member States by a third-country national or a stateless person and on requests for the comparison with Eurodac data by Member States' law enforcement authorities and Europol for law enforcement purposes, and amending Regulation (EU) No. 1077/2011 establishing a European Agency for the operational management of large-scale IT systems in the area of freedom, security and justice ${ }^{23}$

- Commission Regulation (EC) No. 1560/2003 of 2 September 2003 laying down detailed rules for the application of Council Regulation (EC) No. 343/2003 establishing the criteria and mechanisms for determining the Member State responsible for examining an asylum application lodged in one of the Member States by a third-country national $^{24}$

- Proposal COM(2016)0272 final [2016/0132 (COD)] for a Regulation of the European Parliament and of the Council for a on the establishment of 'Eurodac' for the comparison of fingerprints for the effective application of [Regulation (EU) No. 604/2013 establishing the criteria and mechanisms for determining the Member State responsible for examining an application for international protection lodged in one of the Member States by a third-country national or a stateless person], for identifying an illegally staying third-country national or stateless person and on requests for the comparison with Eurodac data by Member States' law enforcement authorities and Europol for law enforcement purposes (recast)

- Amended proposal COM(2020) 614 final [2016/0132(COD)] for a Regulation of the European Parliament and of the Council on the establishment of 'Eurodac' for the comparison of biometric data for the effective application of Regulation (EU) XXX/ XXX [Regulation on Asylum and Migration Management] and of Regulation (EU) XXX/XXX [Resettlement Regulation], for identifying an illegally staying third-country national or stateless person and on requests for the comparison with Eurodac data by Member States' law enforcement authorities and Europol for law enforcement purposes and amending Regulations (EU) 2018/1240 and (EU) 2019/818

- Proposal COM(2020) 612 final [2020/0278(COD)] for a Regulation of the European Parliament and of the Council introducing a screening of third country nationals at the external borders and amending Regulations (EC) No. 767/2008, (EU) 2017/2226, (EU) 2018/1240 and (EU) 2019/817 


\section{Entry-Exit System (EES)}

- Regulation (EU) 2017/2225 of the European Parliament and of the Council of 30 November 2017 amending Regulation (EU) 2016/399 as regards the use of the Entry/ Exit System ${ }^{25}$

- Regulation (EU) 2017/2226 of the European Parliament and of the Council of 30 November 2017 establishing an Entry/Exit System (EES) to register entry and exit data and refusal of entry data of third-country nationals crossing the external borders of the Member States and determining the conditions for access to the EES for law enforcement purposes, and amending the Convention implementing the Schengen Agreement and Regulations (EC) No. 767/2008 and (EU) No. 1077/201126

- Commission Implementing Decision (EU) 2018/1547 of 15 October 2018 laying down the specifications for the connection of the central access points to the Entry/ Exit System (EES) and for a technical solution to facilitate the collection of data by Member States for the purpose of generating statistics on the access to the EES data for law enforcement purposes ${ }^{27}$

- Commission Implementing Decision (EU) 2019/326 of 25 February 2019 laying down measures for entering the data in the Entry/Exit System (EES) ${ }^{28}$

- Commission Implementing Decision (EU) 2019/329 of 25 February 2019 laying down the specifications for the quality, resolution and use of fingerprints and facial image for biometric verification and identification in the Entry/Exit System (EES) ${ }^{29}$

\section{European Travel Information and Authorization System (ETIAS)}

- Regulation (EU) 2018/1240 of the European Parliament and of the Council of 12 September 2018 establishing a European Travel Information and Authorization System (ETIAS) and amending Regulations (EU) No. 1077/2011, (EU) No. 515/2014, (EU) 2016/399, (EU) 2016/1624 and (EU) 2017/2226 $6^{30}$

- Regulation (EU) 2018/1241 of the European Parliament and of the Council of 12 September 2018 amending Regulation (EU) 2016/794 for the purpose of establishing a European Travel Information and Authorization System (ETIAS) ${ }^{31}$

\section{European Criminal Records Information System for Third Country Nationals (ECRIS- TCN)}

- Council Framework Decision 2009/315/JHA of 26 February 2009 on the organisation and content of the exchange of information extracted from the criminal record between Member States ${ }^{32}$

- Council Decision 2009/316/JHA of 6 April 2009 on the establishment of the European Criminal Records Information System (ECRIS) in application of Article 11 of Framework Decision 2009/315/JHA ${ }^{33}$

- Regulation (EU) 2019/816 of the European Parliament and of the Council of 17 April 2019 establishing a centralised system for the identification of Member States holding conviction information on third-country nationals and stateless persons 
(ECRIS-TCN) to supplement the European Criminal Records Information System and amending Regulation (EU) 2018/1726 $6^{34}$

- Directive (EU) 2019/884 of the European Parliament and of the Council of 17 April 2019 amending Council Framework Decision 2009/315/JHA, as regards the exchange of information on third-country nationals and as regards the European Criminal Records Information System (ECRIS), and replacing Council Decision 2009/316/JHA ${ }^{35}$

\section{Interoperability}

- Regulation (EU) 2019/817 of the European Parliament and of the Council of 20 May 2019 on establishing a framework for interoperability between EU information systems in the field of borders and visa and amending Regulations (EC) No. 767/2008, (EU) 2016/399, (EU) 2017/2226, (EU) 2018/1240, (EU) 2018/1726 and (EU) $2018 / 1861$ of the European Parliament and of the Council and Council Decisions 2004/512/EC and 2008/633/JHA ${ }^{36}$

- Regulation (EU) 2019/818 of the European Parliament and of the Council of 20 May 2019 on establishing a framework for interoperability between EU information systems in the field of police and judicial cooperation, asylum and migration and amending Regulations (EU) 2018/1726, (EU) 2018/1862 and (EU) 2019/816 ${ }^{37}$

\section{Prüm Convention}

- Council Decision 2008/615/JHA of 23 June 2008 on the stepping up of cross-border cooperation, particularly in combating terrorism and cross-border crime ${ }^{38}$

- Council Decision 2008/616/JHA of 23 June 2008 on the implementation of Decision 2008/615/JHA on the stepping up of cross-border cooperation, particularly in combating terrorism and cross-border crime ${ }^{39}$

\section{European Border Surveillance System (Eurosur)}

- Regulation (EU) No. 1052/2013 of the European Parliament and of the council of 22 October 2013 establishing the European Border Surveillance System (Eurosur) ${ }^{40}$

- Regulation (EU) 2019/1896 of the European Parliament and of the Council of 13 November 2019 on the European Border and Coast Guard and repealing Regulations (EU) No. 1052/2013 and (EU) 2016/1624

\section{Passenger Name Records (PNR)}

- Directive (EU) 2016/681 of the European Parliament and of the Council of 27 April 2016 on the use of passenger name record (PNR) data for the prevention, detection, investigation and prosecution of terrorist offences and serious crime ${ }^{42}$

- Passenger name records (PNR) Updated list of Member States who have decided the application of the PNR Directive to intra-EU flights as referred to in Article 2 of Directive (EU) 2016/681 of the European Parliament and of the Council on the use of 
passenger name record (PNR) data for the prevention, detection, investigation and prosecution of terrorist offences and serious crime ${ }^{43}$

- Passenger name records (PNR) - Passenger Information Units - List of the Passenger Information Units referred to in Article 4 of Directive (EU) 2016/681 of the European Parliament and of the Council on the use of passenger name record (PNR) data for the prevention, detection, investigation and prosecution of terrorist offences and serious crime ${ }^{44}$

- Agreement between the European Union and Australia on the processing and transfer of Passenger Name Record (PNR) data by air carriers to the Australian Customs and Border Protection Service ${ }^{45}$

- Agreement between the United States of America and the European Union on the use and transfer of passenger name records to the United States Department of Homeland Security ${ }^{46}$

\section{API}

- Council Directive 2004/82/EC of 29 April 2004 on the obligation of carriers to communicate passenger data ${ }^{47}$

\section{Dual-use}

- Regulation (EC) No. 428/2009 of 5 May 2009 setting up a Community regime for the control of exports, transfer, brokering and transit of dual-use items ${ }^{48}$

\section{Unmanned aircraft systems}

- Commission Delegated Regulation (EU) 2019/945 of 12 March 2019 on unmanned aircraft systems and on third-country operators of unmanned aircraft systems ${ }^{49}$

- Commission Implementing Regulation (EU) 2019/947 of 24 May 2019 on the rules and procedures for the operation of unmanned aircraft ${ }^{50}$

\section{Passports}

- Council Regulation (EC) No. 2252/2004 of 13 December 2004 on standards for security features and biometrics in passports and travel documents issued by Member States

- International Civil Aviation Organization (ICAO) Doc 9303 Machine Readable Travel Documents, 7 th edition, $2015^{51}$

\section{Identity cards}

- Regulation (EU) 2019/1157 of the European Parliament and of the Council of 20 June 2019 on strengthening the security of identity cards of Union citizens and of residence documents issued to Union citizens and their family members exercising their right of free movement ${ }^{52}$ applicable from 2 August 2021

- ICAO Doc 9303 Machine Readable Travel Documents, 7th edition, 2015 


\section{EU bodies and agencies}

- Regulation (EU) 2018/1726 of the European Parliament and of the Council of 14 November 2018 on the European Union Agency for the Operational Management of Large-Scale IT Systems in the Area of Freedom, Security and Justice (eu-LISA), and amending Regulation (EC) No. 1987/2006 and Council Decision 2007/533/JHA and repealing Regulation (EU) No. 1077/2011 ${ }^{53}$

- Regulation (EU) 2019/1896 of the European Parliament and of the Council of 13 November 2019 on the European Border and Coast Guard and repealing Regulations (EU) No. 1052/2013 and (EU) 2016/1624 54

- Regulation (EU) No. 439/2010 of the European Parliament and of the Council of 19 May 2010 establishing a European Asylum Support Office ${ }^{55}$

- Regulation (EU) 2016/794 of the European Parliament and of the Council of 11 May 2016 on the European Union Agency for Law Enforcement Cooperation (Europol) and replacing and repealing Council Decisions 2009/371/JHA, 2009/934/JHA, 2009/935/JHA, 2009/936/JHA and 2009/968/JHA ${ }^{56}$

- Proposal COM(2020)796 final [2020/0349(COD)] for a Regulation of the European Parliament and of the Council amending Regulation (EU) 2016/794, as regards Europol's cooperation with private parties, the processing of personal data by Europol in support of criminal investigations, and Europol's role on research and innovation

- Regulation (EU) 2018/1727 of the European Parliament and of the Council of 14 November 2018 on the European Union Agency for Criminal Justice Cooperation (Eurojust), and replacing and repealing Council Decision 2002/187/JHA ${ }^{57}$

\section{Endnotes}

1. The list also contains non-legally binding proposals aimed at updating current instruments.

2. OJ C 326, 26.10.2012, pp. 13-390.

3. OJ C 326, 26.10.2012, pp. 47-390.

4. OJ C 326, 26.10.2012, pp. 391-407.

5. OJ L 239, 22.9.2000, pp. 13-18.

6. OJ L 239, 22.9.2000, pp. 19-62.

7. OJ L 381, 28.12.2006, pp. 1-3.

8. OJ L 381, 28.12.2006, pp. 4-23.

9. OJ L 205, 7.8.2007, pp. 63-84.

10. OJ L 112, 5.5.2010, pp. 31-37.

11. OJ L 77, 23.3.2016, pp. 1-52.

12. OJ L 71, 14.3.2013, pp. 1-36.

13. OJ L 231, 7.9.2017, pp. 6-51.

14. OJ L 312, 7.12.2018, pp. 1-13.

15. OJ L 312, 7.12.2018, pp. 14-55.

16. OJ L 312, 7.12.2018, pp. 56-106.

17. OJ L 213, 15.6.2004, pp. 5-7. 
18. OJ L 218, 13.8.2008, pp. 60-81.

19. OJ L 218, 13.8.2008, pp. 129-136.

20. OJ L 243, 15.9.2009, pp. 1-58.

21. OJ L 267, 27.9.2006, pp. 41-43.

22. OJ L 180, 29.6.2013, pp. 31-59.

23. OJ L 180, 29.6.2013, pp. 1-30.

24. OJ L 222, 5.9.2003, pp. 3-23.

25. OJ L 327, 9.12.2017, pp. 1-19.

26. OJ L 327, 9.12.2017, pp. 20-82.

27. OJ L 259, 16.10.2018, pp. 35-38.

28. OJ L 57, 26.2.2019, pp. 5-9.

29. OJ L 57, 26.2.2019, pp. 18-28.

30. OJ L 236, 19.9.2018, pp. 1-71.

31. OJ L 236, 19.9.2018, pp. 72-73.

32. OJ L 93, 7.4.2009, pp. 23-32.

33. OJ L 93, 7.4.2009, pp. 33-48.

34. OJ L 135, 22.5.2019, pp. 1-26.

35. OJ L 151, 7.6.2019, pp. 143-150.

36. OJ L 135, 22.5.2019, pp. 27-84

37. OJ L 135, 22.5.2019, pp. 85-135.

38. OJ L 210, 6.8.2008, pp. 1-11.

39. OJ L 210, 6.8.2008, pp. 12-72.

40. OJ L 295, 6.11.2013, pp. 11-26.

41. See in particular Chapter II Section 3 and Article 89; OJ L 295, 14.11.2019, pp. 1-131.

42. OJ L 119, 4.5.2016, pp. 132-14.

43. OJ C $358,26.10 .2020$, p. 7.

44. OJ C 230, 2.7.2018, p. 6.

45. OJ L 186, 14.7.2012, pp. 4-16.

46. OJ L 215, 11.8.2012, pp. 5-14.

47. OJ L 261, 6.8.2004, pp. 24-27.

48. OJ L 134, 29.5.2009, pp. 1-269.

49. OJ L 152, 11.6.2019, pp. 1-40.

50. OJ L 152, 11.6.2019, pp. 45-71.

51. Cf. https://www.icao.int/publications/pages/publication.aspx?docnum=9303.

52. OJ L 188, 12.7.2019, pp. 67-78.

53. OJ L 295, 21.11.2018, pp. 99-137.

54. OJ L 295, 14.11.2019, pp. 1-131.

55. OJ L 132, 29.5.2010, pp. 11-28.

56. OJ L 135, 24.5.2016, pp. 53-114.

57. OJ L 295, 21.11.2018, pp. 138-183. 